\title{
Bioethanol production from hydrothermal pretreated wheat straw by a flocculating Saccharomyces cerevisiae strain - Effect of process conditions
}

\author{
Héctor A. Ruiz $^{\mathrm{a}, *}$, Daniel P. Silva ${ }^{\mathrm{b}}$, Denise S. Ruzene ${ }^{\mathrm{b}}$, Luis F. Lima ${ }^{\mathrm{a}}$, António A. Vicente ${ }^{\mathrm{a}}$, José A. Teixeira ${ }^{\mathrm{a}}$ \\ a IBB - Institute for Biotechnology and Bioengineering, Centre of Biological Engineering, University of Minho, Campus de Gualtar, 4710-057 Braga, Portugal \\ ${ }^{\mathrm{b}}$ ITP - Institute of Technology and Research, University Tiradentes, Campus Farolândia, 49032-490 Aracaju-SE, Brazil
}

\section{A R T I C L E I N F O}

\section{Article history:}

Received 8 September 2011

Received in revised form 23 October 2011

Accepted 25 October 2011

Available online 10 November 2011

\section{Keywords:}

Bioethanol

Hydrothermal pretreatment

Flocculating yeast

Simultaneous saccharification and

fermentation (SSF)

Wheat straw

\begin{abstract}
A B S T R A C T
Wheat straw is nowadays being considered a potential lignocellulose raw material for fuel ethanol production of second generation and as an alternative to conventional fuel ethanol production from cereal crops. In the present study, hydrothermal pretreated wheat straw with high cellulose content $(>60 \%)$ at $180^{\circ} \mathrm{C}$ for $30 \mathrm{~min}$ was used as substrate in simultaneous saccharification and fermentation (SSF) process for bioethanol production using a thermotolerant flocculating strain of Saccharomyces cerevisiae CA11. In order to evaluate the effects of temperature, substrate concentration (as effective cellulose) and enzyme loading on: (1) ethanol conversion yield, (2) ethanol concentration, and (3) $\mathrm{CO}_{2}$ concentration a central composite design (CCD) was used. Results showed that the ethanol conversion yield was mainly affected by enzyme loading, whereas for ethanol and $\mathrm{CO}_{2}$ concentration, enzyme loading and substrate concentration were found to be the most significant parameters. The highest ethanol conversion yield of $85.71 \%$ was obtained at $30^{\circ} \mathrm{C}, 2 \%$ substrate and $30 \mathrm{FPU}$ of enzyme loading, whereas the maximum ethanol and $\mathrm{CO}_{2}$ concentrations ( 14.84 and $14.27 \mathrm{~g} / \mathrm{L}$, respectively) were obtained at $45^{\circ} \mathrm{C}, 3 \%$ substrate and $30 \mathrm{FPU}$ of enzyme loading, corresponding to an ethanol yield of $82.4 \%$, demonstrating a low enzyme inhibition and a good yeast performance during SSF process. The high cellulose content obtained in hydrothermal pretreatment and the use of a thermotolerant flocculating strain of S. cerevisiae in SSF suggest as a very promising process for bioethanol production.
\end{abstract}

(ㄷ) 2011 Elsevier Ltd. All rights reserved.

\section{Introduction}

Bioethanol is an increasingly important alternative fuel for the replacement of gasoline, with a world production in 2009 of 19,535 millions of gallons and an estimate, only for USA in 2022 , of 36,000 millions of gallons. It is thus expected that the production of bioethanol will keep on increasing in the next 10 years (Fig. 1) [1]. Second-generation bioethanol obtained from lignocellulosic materials (LCM) has received major attention due to their abundance and immense potential for conversion into sugars and fuels. However, there are relevant obstacles such as production costs, technology and environmental problems that need to be overcome in the production of second-generation bioethanol [2-4]. Wheat straw is one of the most abundant agricultural by-products, presents a low commercial value and most of it is being used as cattle feed and waste. In terms of total production, wheat is the second most important grain crop in the world. FAO statistics reported a world annual wheat production in 2009 of 682 million tons and, in average, the harvesting of $1.3 \mathrm{~kg}$ of grain is accompanied by the production of $1 \mathrm{~kg}$ of straw; this gives an estimation of about

\footnotetext{
* Corresponding author. Tel.: +351 253604 400; fax: +351253678986.

E-mail address: hector_ruiz@deb.uminho.pt (H.A. Ruiz).
}

524 million tons of wheat straw in 2009 , an amount that clearly justifies the need to consider wheat straw as a complementary source of raw material for the production of bioethanol $[5,6]$.

The process for the production of second-generation bioethanol includes three main steps: pretreatment, enzymatic hydrolysis and fermentation. Hydrothermal processing (autohydrolysis), a pretreatment based in the use hot compressed water, presents several advantages; no chemicals other than water are needed, no problems derived from equipment corrosion occur, toxic compounds formation is minimized, a high recovery of valuable hemicellulose derived products is obtained and cellulose structure is made susceptible to enzymatic hydrolysis [7-9]. Simultaneous saccharification and fermentation (SSF) processes, firstly described by Takagi et al. [10], combine enzymatic hydrolysis of cellulose with simultaneous fermentation of the obtained sugars to ethanol and are one the most promising process option for bioethanol production from LCM [11]. SSF process has shown to be superior to separate hydrolysis and fermentation (SHF) in terms of overall ethanol yield. Furthermore, SSF reduces the processing time, which in turn leads to increases in ethanol productivity this is a consequence of the fast conversion of glucose to ethanol by the fermenting microorganisms, that reduce the enzymes inhibition due the presence of sugars. Reduction in equipment costs is also obtained by performing the 


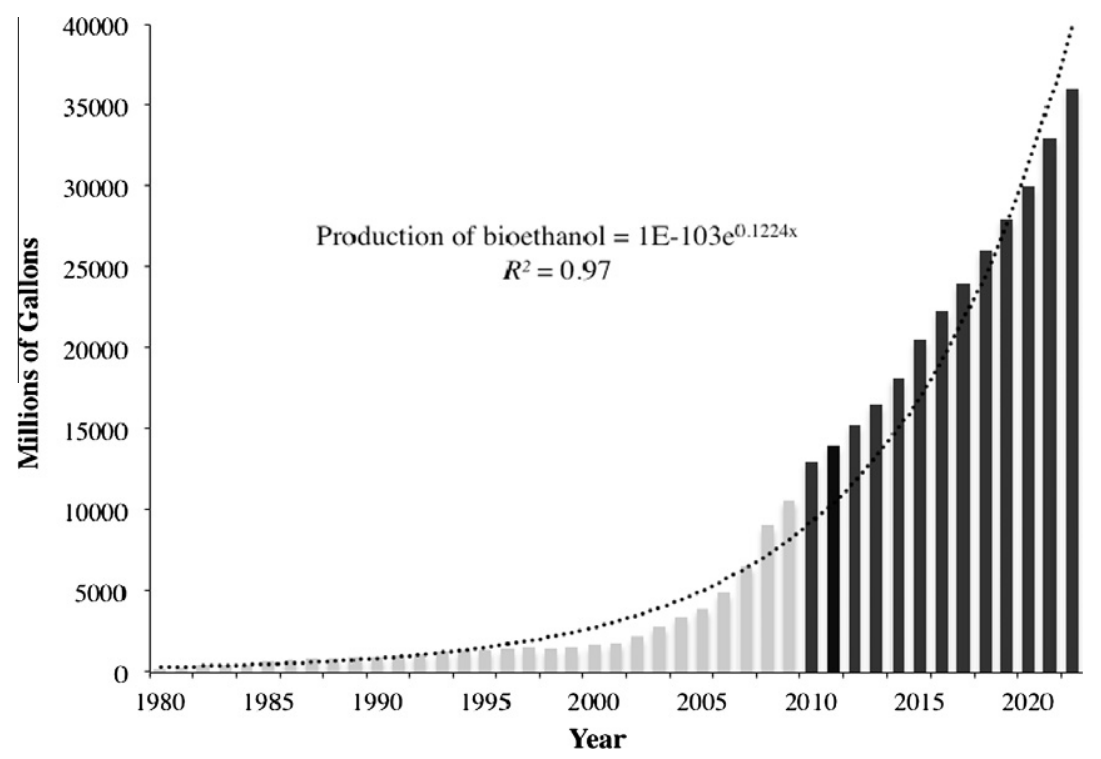

Fig. 1. Trends in US fuel ethanol production; ( $\square$ ) real production; ( $\square$ ) estimate production. The points represent the trend model.

hydrolysis and fermentation in a single reactor. However, differences between the optimal temperature for cellulose activity and yeast growth is an issue that needs to be solved for an efficient SSF. The optimal temperature for cellulase enzymes (about of $50{ }^{\circ} \mathrm{C}$ ) is higher than the tolerance range reported by the most used yeast for industrial ethanol production (about $30-37^{\circ} \mathrm{C}$ ) [12-16]. This requires the matching of the temperature conditions required for the optimum performance of the enzymatic and the fermenting microorganism.

On the other hand, yeasts isolated from extreme environments, exhibit the capability of growth at high temperatures while producing ethanol; a proof of this is the industrial ethanol fermentation in some tropical countries as Brazil where fermentation takes place at ambient temperatures and during the process the temperature can reach $41{ }^{\circ} \mathrm{C}$ as, due to its expensive costs [17], no cooling systems are used. This requires the use of yeast strains able to produce high ethanol yields at such high temperatures. Abdel-Banat et al. [18] demonstrated that if the fermentation step could be performed at higher temperatures, for instance within a $40-50{ }^{\circ} \mathrm{C}$ range, significant cost reductions in fuel ethanol production could be obtained. Advantages of processing at higher temperatures include a more-efficient simultaneous saccharification and fermentation, significant reduction of contamination and a continuous shift from fermentation to distillation $[19,20]$.

Additionally, the use of flocculating yeasts is one of the most interesting ways to provide an increase of the efficiency of bioethanol production processes as a significant reduction of capital costs is achieved with the elimination of centrifugation (or at least a substantial reduction of the demand for such an expensive operation), making the process more competitive. The flocculation of yeast cells is a reversible, asexual and calcium-dependent process in which cells adhere to form flocs consisting of thousands of cells, the use of high cell density systems being investigated and used for separating yeast cells from beer in the brewing industry. In fact, these systems present several advantages as reduced downstream processing costs, reuse of the biomass for extended periods of time, higher productivity, protection against ethanol stress and resistance to contamination by other microorganism [21-25]. Overall, improved efficiency of the SSF will be obtained by using a yeast strain that can work at higher temperatures and has flocculant properties.

The aim of the present work was to evaluate the effect of SSF operating conditions (temperature, substrate and enzyme loading) of hydrothermal pretreated wheat straw as substrate on ethanol conversion yield, ethanol and $\mathrm{CO}_{2}$ production with a flocculating strain Saccharomyces cerevisiae CA11.

\section{Materials and methods}

\subsection{Wheat straw pretreatment by hydrothermal processing}

Wheat straw used as raw material in this study and was kindly provided by a local farmer (Elvas, Portugal). Wheat straw was cut into small pieces $(1-3 \mathrm{~cm}$ ) and milled using a laboratory knife mill (Cutting Mill SM 2000, Retsch, Germany). The material composition was previously analyzed by Ruiz et al. [9], containing cellulose (glucan) as the most abundant fraction (37.4\%) followed by xylan (29.4\%), lignin (26.8\%), arabinan (1.9\%), and ash (1.6\%). This chemical composition is in good agreement with other values found in the literature for this material [26,27]. The particle size distribution (w/ w\%) used in this work was as follows: $10 \%>1 \mathrm{~mm}$; $40 \%$ between $1-$ $0.5 \mathrm{~mm} ; 40 \%$ between $0.5-0.3 \mathrm{~mm}$; and $10 \%$ to $<0.3 \mathrm{~mm}$. The same batch of raw material was used for all experiments.

Milled wheat straw samples were mixed with water in order to obtain a 10:1 liquid/solid mass ratio and treated in a $3.75 \mathrm{~L}$ total volume stainless steel reactor (Parr Instruments Company, Moline, Illinois, USA) with PID temperature control. The moisture content of wheat straw was considered as water in the material balances. The reactor was filled and heated to $180{ }^{\circ} \mathrm{C}$ at a heating rate of $3{ }^{\circ} \mathrm{C} / \mathrm{min}$ until reaching the desired temperature, the reaction time was $30 \mathrm{~min}$, these conditions having been previously evaluated by Ruiz et al. [9]. After completing the reaction time, the reactor was cooled down at a rate about of $3.2{ }^{\circ} \mathrm{C} / \mathrm{min}$ and the agitation speed was set at $135 \mathrm{rpm}$. Fig. 2 shows a typical and excellent reproducibility of the heating and cooling temperature profiles obtained for a triplicate experiment at $180^{\circ} \mathrm{C}$. At the end of the treatment, the liquid and solid phases were separated by centrifugation and the solid residues were washed with distilled water. Quantification of structural carbohydrates, sugars and degradation products in both solid and liquid phases has been previously reported by Ruiz et al. [28]. The solid residue was used as substrate for simultaneous saccharification and fermentation.

\subsection{Yeast strain cultivation}

The flocculating S. cerevisiae CA11 was obtained from the microbial collection at the Microbial Physiology Laboratory/Department 


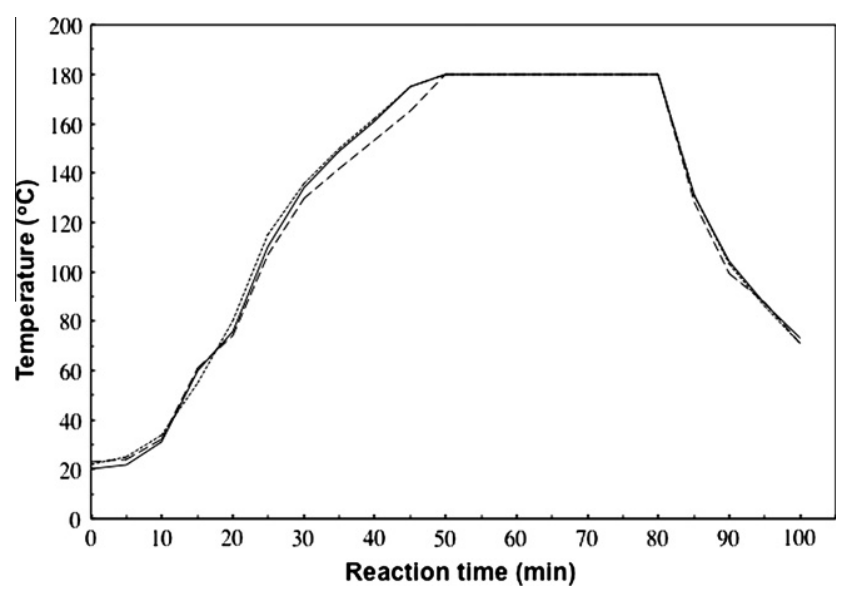

Fig. 2. Temperature profiles for hydrothermal pretreatment at $180^{\circ} \mathrm{C}$ for $30 \mathrm{~min}$.

of Biology from the Federal University of Lavras (UFLA), Brazil. The flocculating yeast strain was isolated from a "cachaça" distillery in the state of Minas Gerais, Brazil and used in all the fermentation experiments. The strain was kept on agar plates made of $10 \mathrm{~g} / \mathrm{L}$ yeast extract, $20 \mathrm{~g} / \mathrm{L}$ peptone, $20 \mathrm{~g} / \mathrm{L}$ agar and $20 \mathrm{~g} / \mathrm{L}$ D-glucose as an additional carbon source at $4{ }^{\circ} \mathrm{C}$.

\subsection{Yeast inoculum preparation}

Yeast for inoculation was grown in $250 \mathrm{~mL}$ Erlenmeyer flasks with $125 \mathrm{~mL}$ of sterile culture medium containing $50 \mathrm{~g} / \mathrm{L}$ glucose, $10 \mathrm{~g} / \mathrm{L}$ peptone, $10 \mathrm{~g} / \mathrm{L}$ yeast extract, $0.5 \mathrm{~g} / \mathrm{L}\left(\mathrm{NH}_{4}\right)_{2} \mathrm{HPO}_{4}$ and $0.5 \mathrm{~g} / \mathrm{L} \mathrm{MgSO}_{4} .7 \mathrm{H}_{2} \mathrm{O}$; glucose was sterilized separately from the other components to prevent damage to the nutritional qualities of the medium. Yeast growth was carried out at $30^{\circ} \mathrm{C}$ and $150 \mathrm{rpm}$ in an orbital shaker for 10-12 h. The cell suspension was aseptically collected by centrifugation $(15 \mathrm{~min}$ at $7885 \mathrm{~g}$, $4{ }^{\circ} \mathrm{C}$ ) and suspended in sterile $0.9 \% \mathrm{NaCl}$ to a concentration of $200 \mathrm{mg}$ fresh yeast $/ \mathrm{mL}$. The yeast cells were inoculated at about $8 \mathrm{mg}$ fresh yeast/mL into $50 \mathrm{~mL}$ of culture medium to start the fermentation [29].

\subsection{Enzyme}

Commercially available enzyme solutions, cellulase from Trichoderma reesei (Celluclast $1.5 \mathrm{~L}$ ) and $\beta$-glucosidase from Aspergillus niger (Novozym 188), were kindly supplied by Novozymes A/S (Bagsvaerd, Denmark). The cellulase activity from Celluclast $1.5 \mathrm{~L}$ was analyzed in terms of FPU in accordance with the standard analytical methods established by the National Renewable Energy Laboratory (NERL) [30]. One filter paper unit (FPU) of cellulase was defined as the amount of enzyme which produces $2.0 \mathrm{mg}$ of reducing sugar from $50 \mathrm{mg}$ of filter paper within $1 \mathrm{~h}$.

The experiment was carried out in a reaction mixture containing $0.5 \mathrm{~mL}$ of diluted enzyme solution, $1.0 \mathrm{~mL}$ of $50 \mathrm{mM}$ citrate buffer ( $\mathrm{pH} 4.8$ ), and $50 \mathrm{mg}$ of a $1 \times 6 \mathrm{~cm}$ strip of a Whatman No. 1 filter paper. The reaction solution was incubated at $50{ }^{\circ} \mathrm{C}$ for $1 \mathrm{~h}$. Then the concentration of the released reducing sugar was measured using an adaptation of the 3,5-dinitrosalicylic acid (DNS) method [31]. $\beta$-Glucosidase activity was determined for Novozym 188. The $\beta$-glucosidase activity was measured by incubating the enzyme solution with $4 \mathrm{mM} p$-nitrophenyl- $\beta$-D-glucopyranoside and $50 \mathrm{mM}$ sodium citrate buffer $\left(\mathrm{pH} \mathrm{4.8)}\right.$ ) at $30^{\circ} \mathrm{C}$ for $15 \mathrm{~min}$. The reaction was stopped by addition of $60 \mu \mathrm{L}$ of $1 \mathrm{M} \mathrm{Na}_{2} \mathrm{CO}_{3}$ and the amount of liberated $p$-nitrophenol was measured spectrophotometrically at $400 \mathrm{~nm}$. One unit of activity (IU) was defined as the release of $1 \mu \mathrm{mol}$ of nitrophenol per minute. The enzyme activities of commercial concentrates were $43.05 \mathrm{FPU} / \mathrm{mL}$ for Celluclast $1.5 \mathrm{~L}$ and $576.39 \mathrm{UI} / \mathrm{mL}$ for Novozym 188.

In our previous work, the susceptibility of hydrothermal pretreated wheat straw to enzymatic saccharification was studied. The results showed that the enzymatic saccharification conversion of cellulose to glucose was $90.88 \%$ [32].

\subsection{Simultaneous saccharification and fermentation (SSF)}

The SSF experiment was conducted in accordance with NREL standard procedure [33]. The fermentations were performed in $100 \mathrm{~mL}$ Erlenmeyer flasks and each one was equipped with a thick rubber stopper, through which one stainless-steel capillary had been inserted; the exterior tip was submerged in glycerol. Glycerol was used as a lock to prevent oxygen back-diffusion to the medium, while permitting evolved $\mathrm{CO}_{2}$ to leave the flask and to maintain anaerobic conditions. The fermentation medium contained pretreated wheat straw, $1 \% \mathrm{w} / \mathrm{v}$ yeast extract, $2 \% \mathrm{w} / \mathrm{v}$ peptone, $50 \mathrm{mM}$ citrate buffer ( $\mathrm{pH} 4.8$ ), cellulase and $\beta$-glucosidase enzyme. The $\beta$-glucosidase enzyme was added at a ratio of $2: 1 \mathrm{U}$ of $\beta$-glucosidase to FPU of cellulase. Spindler et al. [34] reported that the $\beta$-glucosidase supplementation is necessary to achieve efficient cellulose conversion. The necessary amount of deionized water was calculated and added to make the total weight of $50 \mathrm{~g}$. The pretreated wheat straw was used as the control. SSF was started by adding enzymes and flocculating S. cerevisiae CA 11 and then incubated at different conditions (Table 1 ) in an orbital shaker at $150 \mathrm{rpm}$. All the experiments were carried out under sterile conditions. Samples of $1 \mathrm{~mL}$ were withdrawn aseptically with sterile pipette tips at $3 \mathrm{~h}$ intervals for the first $12 \mathrm{~h}$ and at $24 \mathrm{~h}$ intervals until a total of $96 \mathrm{~h}$. Samples were immediately cooled on ice and centrifuged at $8260 \mathrm{~g}$ for $10 \mathrm{~min}$. Ethanol concentration and that of remaining sugars were determined by means of HPLC (see below). As an estimate, the $\mathrm{CO}_{2}$ was kinetically monitored by weight loss of the Erlenmeyer flasks at regular intervals (the influence of sample withdrawal was taken into account). Fermentation monitoring based on $\mathrm{CO}_{2}$ production is a common practice in wine fermentation $[35,36]$. All determinations were performed in duplicate.

\subsection{Analytical methods}

All samples taken from SSF were filtered through a $0.2 \mu \mathrm{m}$ sterile membrane filter and analyzed for cellobiose, glucose and ethanol by HPLC. Chromatographic separation was performed using a Metacarb $87 \mathrm{H}$ column $(300 \times 7.8 \mathrm{~mm}$, Varian, USA) under the following conditions: mobile phase $0.005 \mathrm{M} \mathrm{H}_{2} \mathrm{SO}_{4}$, flow rate $0.7 \mathrm{~mL} /$ min, and column temperature $60^{\circ} \mathrm{C}$. The system was comprised of a Jasco chromatograph 880-PU intelligent pump (Jasco, Tokyo, Japan) equipped with a Jasco 830-IR intelligent refraction-index detector (Jasco, Tokyo, Japan) and a Jasco AS-2057 Plus intelligent auto sampler (Jasco, Tokyo, Japan). The volume injected was $20 \mu \mathrm{L}$ per sample. Sugars and ethanol concentrations were determined based on calibration curves of these pure compounds [28].

\subsection{Ethanol yield calculations}

The ethanol yield was calculated according to the NERL standard procedure [33].

Ethanol yield $=\frac{[\mathrm{EtOH}]_{f}-[\mathrm{EtOH}]_{0}}{0.51 f[\text { Biomass }] \times 1.111} \times 100 \%$

where $[\mathrm{EtOH}]_{f}$ is the ethanol concentration at the end of the fermentation $(\mathrm{g} / \mathrm{L})$; and $[\mathrm{EtOH}]_{0}$ is the ethanol concentration at the beginning of the fermentation $(\mathrm{g} / \mathrm{L})$. The term " $0.51 \times f \times[$ Bio- 
Table 1

Statistical analysis of experimental design arrangement, responses and predicted values for ethanol yield, ethanol and $\mathrm{CO}_{2}$ concentration.

\begin{tabular}{|c|c|c|c|c|c|c|c|c|c|c|c|c|}
\hline \multirow[t]{2}{*}{ Run } & \multicolumn{3}{|c|}{ Normalized variables $^{a}$} & \multicolumn{3}{|c|}{ Real value } & \multicolumn{2}{|c|}{ Ethanol yield (\%) } & \multicolumn{2}{|l|}{ Ethanol $(\mathrm{g} / \mathrm{L})$} & \multicolumn{2}{|l|}{$\mathrm{CO}_{2}(\mathrm{~g} / \mathrm{L})$} \\
\hline & $X_{1}$ & $X_{2}$ & $X_{3}$ & $x_{1}$ & $x_{2}$ & $x_{3}$ & $\operatorname{Exp}^{\mathrm{b}}\left(Y_{\mathrm{EtOH}}\right)$ & $\operatorname{Pre}^{\mathrm{c}}\left(Y_{\mathrm{EtOH}}\right)$ & $\operatorname{Exp}^{\mathrm{b}}\left(C_{\mathrm{EtOH}}\right)$ & $\operatorname{Pre}^{\mathrm{c}}\left(C_{\mathrm{EtOH}}\right)$ & $\operatorname{Exp}^{\mathrm{b}}\left(C_{\mathrm{CO} 2}\right)$ & $\operatorname{Pre}^{\mathrm{c}}\left(C_{\mathrm{CO} 2}\right)$ \\
\hline 1 & -1 & -1 & -1 & 30 & 2 & 5 & 49.51 & 48.42 & 6.22 & 5.86 & 6.57 & 5.90 \\
\hline 2 & -1 & -1 & +1 & 30 & 2 & 30 & 85.71 & 83.45 & 10.09 & 9.86 & 9.96 & 9.63 \\
\hline 3 & -1 & +1 & +1 & 30 & 3 & 30 & 72.88 & 71.26 & 13.20 & 12.67 & 12.96 & 12.15 \\
\hline 4 & -1 & +1 & -1 & 30 & 3 & 5 & 32.10 & 37.56 & 5.78 & 6.59 & 5.08 & 5.97 \\
\hline 5 & +1 & -1 & -1 & 45 & 2 & 5 & 45.13 & 47.00 & 5.31 & 5.63 & 4.74 & 5.27 \\
\hline 6 & +1 & -1 & +1 & 45 & 2 & 30 & 79.05 & 73.84 & 9.51 & 8.49 & 8.94 & 7.78 \\
\hline 7 & +1 & +1 & +1 & 45 & 3 & 30 & 82.40 & 83.74 & 14.85 & 15.00 & 14.28 & 14.68 \\
\hline 8 & +1 & +1 & -1 & 45 & 3 & 5 & 55.74 & 58.25 & 10.04 & 10.06 & 9.65 & 9.71 \\
\hline 9 & -1 & 0 & 0 & 30 & 2.5 & 17.5 & 52.00 & 51.51 & 7.73 & 8.04 & 6.68 & 7.60 \\
\hline 10 & +1 & 0 & 0 & 45 & 2.5 & 17.5 & 57.56 & 57.05 & 8.56 & 9.09 & 8.39 & 8.55 \\
\hline 11 & 0 & -1 & 0 & 37.5 & 2 & 17.5 & 46.01 & 52.69 & 5.42 & 6.71 & 4.64 & 6.27 \\
\hline 12 & 0 & +1 & 0 & 37.5 & 3 & 17.5 & 59.90 & 52.21 & 10.79 & 10.33 & 10.29 & 9.75 \\
\hline 13 & 0 & 0 & -1 & 37.5 & 2.5 & 5 & 41.06 & 32.31 & 6.10 & 5.31 & 5.78 & 4.97 \\
\hline 14 & 0 & 0 & +1 & 37.5 & 2.5 & 30 & 54.83 & 62.58 & 8.15 & 9.78 & 7.42 & 9.32 \\
\hline 15 & 0 & 0 & 0 & 37.5 & 2.5 & 17.5 & 45.35 & 45.62 & 8.00 & 7.68 & 7.50 & 7.17 \\
\hline 16 & 0 & 0 & 0 & 37.5 & 2.5 & 17.5 & 44.89 & 45.62 & 7.88 & 7.68 & 7.26 & 7.17 \\
\hline 17 & 0 & 0 & 0 & 37.5 & 2.5 & 17.5 & 45.24 & 45.62 & 8.20 & 7.68 & 7.98 & 7.17 \\
\hline 18 & 0 & 0 & 0 & 37.5 & 2.5 & 17.5 & 44.98 & 45.62 & 8.31 & 7.68 & 8.12 & 7.17 \\
\hline
\end{tabular}

${ }^{\text {a }} X_{1}$ : Temperature, $X_{2}$ : Substrate, $X_{3}$ : Enzyme loading.

b Experimental value.

c Model predicted value.

mass $] \times 1.111$ " corresponds to the theoretical ethanol concentration, where [Biomass] is the dry biomass weight concentration at the beginning of the fermentation $(\mathrm{g} / \mathrm{L}) ; f$ is the cellulose fraction of dry biomass $(\mathrm{g} / \mathrm{g}) ; 0.51$ is the conversion factor for glucose to ethanol based on the stoichiometric biochemistry of yeast and 1.111 is the conversion factor for cellulose to equivalent glucose.

The ethanol concentration in the liquid phase was analyzed using HPLC as described above. Then the accurate ethanol yield could be obtained using Eq. (1).

\subsection{Experimental design and statistical analysis}

$N=2^{K}+2 \times K+1$

In order to relate the dependent variables ethanol yield ( $Y_{\mathrm{EtOH}}$, $\%)$, ethanol $\left(C_{\mathrm{EtOH}}, \mathrm{g} / \mathrm{L}\right)$ and $\mathrm{CO}_{2}\left(C_{\mathrm{CO} 2}, \mathrm{~g} / \mathrm{L}\right)$ concentration and independent variables temperature $\left(X_{1},{ }^{\circ} \mathrm{C}\right)$, substrate $\left(X_{2}, \%\right)$ and enzyme loading ( $X_{3}, \mathrm{FPU} / \mathrm{g}$ of cellulose) in the process of SSF with the minimum possible number of experiments, a $2^{n}$ central composite experimental design (CCD) for three factors that enabled the construction of second-order polynomials in the independent variables and the identification of statistical significance in the variables was used [37]. The total number of observations required for three independent variables $(N)$ was calculated using the following equation:where $K$ is the number of independent variables. $N$ is found to be 15 with four replicates at the center point leading to a total number of 18 experiments for the evaluation of SSF process. The values of the independent variables were normalized from -1 to +1 using Eq. (3) to provide the comparison of the coefficients and visualization of the individual independent variables on the response variable. The lowest and the highest levels of variables are given in Table 2 .

$X_{n}=2 \frac{X-\bar{X}}{X_{\max }-X_{\min }}$

where $X$ is the absolute value of the independent variable concerned $\bar{X}$ is the average value of the variable and $X_{\max }$ and $X_{\min }$ are its maximum and minimum value, respectively. The second-order polynomials and calculation of predicted responses were calculated
Table 2

Variables and levels used in the central composite design.

\begin{tabular}{llrrr}
\hline Independent variable & Symbol & \multicolumn{3}{l}{ Range and levels } \\
\cline { 3 - 5 } & & \multicolumn{1}{c}{-1} & \multicolumn{1}{c}{0} & +1 \\
\hline Temperature $\left({ }^{\circ} \mathrm{C}\right)$ & $X_{1}$ & 30 & 37.5 & 45 \\
Substrate $(\%)^{\mathrm{a}}$ & $X_{2}$ & 2 & 2.5 & 3 \\
Enzyme loading & $X_{3}$ & 5 & 17.5 & 30 \\
\hline
\end{tabular}

a (\% Effective cellulose)

b (FPU/g of cellulose).

with MATLAB ${ }^{\circledR}$ Version 7.6.0, R2008a software (MathWorks, Inc., Natick, Massachusetts, USA) to estimate the response of the dependent variables. The mathematical model corresponding to the experimental design is:

$Y_{i}=\beta_{0}+\sum_{i=1}^{3} \beta_{i} x_{i}+\sum_{i=1}^{3} \beta_{i i} x_{i}^{2}+\sum_{i=2}^{2} \sum_{j=i+1}^{3} \beta_{i j} x_{i} x_{j}+\epsilon$

where $Y_{i}$ is the predicted value, $x_{i}$ and $x_{j}$ are the normalized values of the factors, $\beta_{0}$ is a constant coefficient, $\beta i$ are the linear coefficients, $\beta i j(i$ and $j$ ) are the interaction coefficients and $\beta i i$ are the quadratic coefficients and $\varepsilon$ is the random error.

The quality of the fit of the polynomial model equation was evaluated by the coefficient of determination $R^{2}$ and the statistical significance was evaluated by the Fisher's $F$-test for analysis of variance (ANOVA) with a 95\% confidence level. The corresponding variables will be more significant if the absolute $F$-value becomes greater and the $p$-value becomes smaller. The effect of each independent variable and also their interaction effects were determined. ANOVA results generated the Pareto charts of interactions and effects. The experimental design package STATISTICA ${ }^{\text {TM }}$ v 7.0 (Statsoft ${ }^{\circledR}$, Tulsa, OK, USA) was the software used for data analysis.

\section{Results and discussion}

\subsection{Effect of hydrothermal processing on the composition of the solid phase}

The cellulose (glucan) content in the solid residue was of $63.7 \%$, xylan $7.55 \%$, arabinan $0.29 \%$, acetyl groups $1.51 \%$ and klason lignin 
$26.91 \%$, revealing that the glucan was almost not affected by the hydrothermal processing and a solid residue with increased glucan percentage was obtained [28]. This increase of glucan could be correlated to the solubilization of hemicellulose components, because the hemicellulose is more amorphous and less stable than cellulose and, as expected, results show a substantial removal of hemicelluloses during hydrothermal processing [38]. These results are in agreement with the data reported for a similar feedstock; Gullón et al. [39] observed a similar behavior for rye straw and using a similar pretreatment process with switchgrass, Suryawati et al. [40] reported an increase in glucan content from $36.6 \%$ to $56.6 \%$ and a decrease in xylan content from $21.0 \%$ to $2.4 \%$. The klason lignin content follows a similar pattern to glucan and the majority of the lignin content remains in the solid phase. Kristensen et al. [41] reported that hydrothermal pretreatment caused re-localization of lignin on the surface of LCM and subsequently the materials are more susceptible to enzymatic hydrolysis.

\subsection{Kinetics of simultaneous saccharification and fermentation (SSF)}

The experimental design matrix is given in Table 1. Eighteen experiments were performed to evaluate the ethanol yield, ethanol and $\mathrm{CO}_{2}$ concentration using SSF process (performed in duplicate) by a flocculating $S$. cerevisiae CA11 on the hydrothermal pretreated wheat straw. During all SSF assays, continuous increases in ethanol content occurred whereas glucose content remained very low. These results indicate that glucose from enzymatic hydrolysis could be fermented to ethanol by $S$. cerevisiae CA11, thus showing a good fermentation performance by the yeast.

Enzymatic hydrolysis of cellulose to glucose first produced a disaccharide, cellobiose, which was then hydrolyzed to a monosaccharide, glucose. The experiments had a similar pattern for glucose and cellobiose concentration during the initial $12 \mathrm{~h}$ (Fig. 3A and B). No cellobiose accumulation was observed throughout fermentations as it was hydrolyzed to glucose continuously, indicating sufficient $\beta$-glucosidase activity in the cellulase preparation and low inhibition by glucose. Fig. $3 \mathrm{~A}$ and $\mathrm{C}$ shows the concentration profiles determined for glucose and ethanol in the experiments 2, 4, 5,7 and 11 of Table 1 . Glucose from enzymatic hydrolysis was rapidly consumed by $S$. cerevisiae indicated by a decrease in glucose from 0 to $12 \mathrm{~h}$ and, in other cases, from 0 to $24 \mathrm{~h}$ (Fig. 3A). Ethanol concentration remained relatively constant, indicating cessation of fermentation. The SSF process was completed after $48 \mathrm{~h}$. The highest ethanol concentration on the pretreated wheat straw was $14.85 \mathrm{~g} / \mathrm{L}$ at $45^{\circ} \mathrm{C}$ for an enzyme loading of $30 \mathrm{FPU} / \mathrm{g}$ cellulose with $3 \%$ of effective cellulose (experiment No. 7), corresponding to an ethanol yield of $82.40 \%$ and $14.28 \mathrm{~g} / \mathrm{L}$ of $\mathrm{CO}_{2}$. The greatest ethanol yield observed was $85.71 \%$ (experiment No. 2), and the lowest ethanol yield observed was $32.10 \%$ at $30{ }^{\circ} \mathrm{C}$ (experiment No. 4 ) in both cases with enzyme loadings of 30 and $5 \mathrm{FPU} / \mathrm{g}$ cellulose, respectively.

The greatest $\mathrm{CO}_{2}$ concentration was $14.27 \mathrm{~g} / \mathrm{L}$ (experiment No. 7 ) and the lowest was $4.64 \mathrm{~g} / \mathrm{L}$ (experiment No. 11). Table 1 shows the theoretical ethanol yield, ethanol and $\mathrm{CO}_{2}$ concentration for each temperature/substrate/enzyme loading combination; results indicate that larger ethanol yields suggest greater hydrolysis of cellulose to glucose. Walsum et al. [42] reported an ethanol production of $18 \mathrm{~g} / \mathrm{L}$ with $90 \%$ of final conversion in $75 \mathrm{~h}$ using the same pretreatment and hard wood flour as raw material and Negro et al. [43] achieved ethanol concentration of $20 \mathrm{~g} / \mathrm{L}$ in $72 \mathrm{~h}$ using poplar biomass in SSF process using steam explosion pretreatment.

\subsection{Statistical analysis}

Multiple regression analysis and analysis of variance (ANOVA) of the experimental data were performed for the mathematical
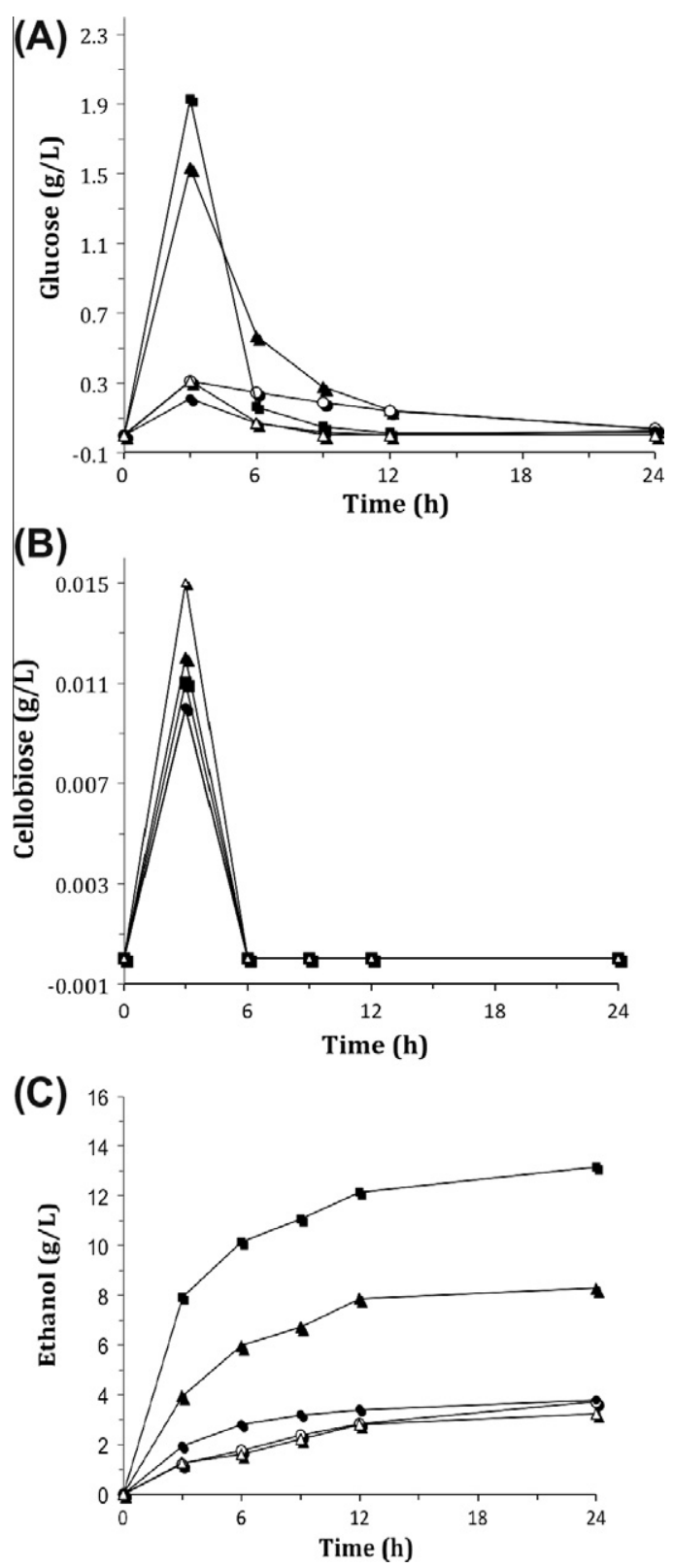

Fig. 3. Glucose, cellobiose and ethanol concentrations obtained in SSF assays carried out under the condition of experiments $2,4,5,7$ and 11 of Table $1.45{ }^{\circ} \mathrm{C}, 3 \%$ of cellulose, $30 \mathrm{FPU}$ of enzyme $(\boldsymbol{\square}) ; 30^{\circ} \mathrm{C}, 2 \%$ of cellulose, $30 \mathrm{FPU}$ of enzyme ( $\left.\mathbf{\Delta}\right)$; $45{ }^{\circ} \mathrm{C}, 2 \%$ of cellulose, 5 FPU of enzyme $(\bullet) ; 30^{\circ} \mathrm{C}, 3 \%$ of cellulose, 5 FPU of enzyme (○); $37.5^{\circ} \mathrm{C}, 2 \%$ of cellulose, $17.5 \mathrm{FPU}$ of enzyme $(\triangle)$.

model fitting. The models in terms of normalized values (Table 2) expressed in Eqs. (5)-(7) represent the ethanol yield, $Y_{\mathrm{EtOH}(\%)}$, ethanol concentration, $C_{\mathrm{EtOH}}$, and $C_{\mathrm{CO} 2}$ concentration, as function of temperature $\left(X_{1}\right)$, substrate $\left(X_{2}\right)$ and enzyme loading $\left(X_{3}\right)$, respectively. Table 1 shows the values predicted by the model applying multiple regression.

$$
\begin{aligned}
Y_{\mathrm{EtoH}}(\%)= & 45.61+2.76 X_{1}-0.23 X_{2}+15.13 X_{3}+5.52 X_{1} X_{2} \\
& -2.05 X_{1} X_{3}-0.33 X_{2} X_{3}+8.66 X_{1}^{2}+6.83 X_{2}^{2}+1.82 X_{3}^{2} \\
& \left(R^{2}=0.924\right)
\end{aligned}
$$

$C_{\mathrm{EtOH}}=7.67+0.52 X_{1}-1.81 X_{2}+2.23 X_{3}+0.92 X_{1} X_{2}-0.28 X_{1} X_{3}$$$
-0.52 X_{2} X_{3}+0.88 X_{1}^{2}+0.84 X_{2}^{2}+0.13 X_{3}^{2}\left(R^{2}=0.923\right)
$$ 


$$
\begin{aligned}
C_{\mathrm{CO}_{2}}= & 7.17+0.47 X_{1}+1.74 X_{2}+2.17 X_{3}+1.09 X_{1} X_{2}-0.30 X_{1} X_{3} \\
& -0.61 X_{2} X_{3}+0.90 X_{1}^{2}+0.83 X_{2}^{2}+0.28 X_{3}^{2}\left(R^{2}=0.892\right)
\end{aligned}
$$

The ANOVA results listed in Tables 3-5 revealed that second-order polynomial models adequately represent responses of ethanol yield, ethanol and $\mathrm{CO}_{2}$ concentration with coefficients of determination $R^{2}$, indicating that $92.4 \%, 92.3 \%$ and $89.2 \%$ of the variability in the responses could be explained by the models. These values were in reasonable agreement with the adjusted determination coefficient $R^{2} a d j=0.838,0.84$ and 0.771 respectively. As shown in Table 3, for ethanol yield, the model F-value of 10.81 is high compared to the tabular $F_{9,8}$ value of 3.39 indicating that the model was significant. The same situation occurred with the models for ethanol and $\mathrm{CO}_{2}$ concentration, where the model $F$-value is 10.74 and 7.37 respectively.

According to ANOVA results for ethanol yield (Table 3 ), all the linear $X_{1}, X_{2}, X_{3}$, square $X_{1}^{2}, X_{2}^{2}, X_{3}^{2}$ and interactions $X_{1} X_{2}, X_{1} X_{3}$, $X_{1} X_{2}$ terms have significant effect on ethanol yield responses with $p$-value under a significance level of $\alpha=0.05$. These effects can be visualized in the standardized Pareto charts (Fig. 4A). It can be observed that enzyme loading, temperature-substrate interactions and temperature are important variables at the $95 \%$ confidence level on the ethanol yield and that the effect of enzyme loading, when raised from the lowest to the highest level, is positive (Fig $4 \mathrm{~A}$ ). This positive effect of $X_{3}$ shows that ethanol yield is improved at higher enzyme loadings. This is consistent since the ethanol yield was high for the conditions tested. Li et al. [44] observed that during the SSF process, ethanol yield was $94.7 \%$ using similar conditions and bermudagrass as raw material. Linde et al. [45] evaluated the influence of low enzyme loading on SSF using the same raw material obtaining an ethanol yield of $67 \%$. Varga et al. [35] reported an ethanol yield of $75 \%$ using high solids concentration in SSF and concluded that increased enzyme loadings accelerated the enzyme reaction, resulting in higher ethanol yield. When observed in terms of temperature, yields increased with increases in temperature up to $45^{\circ} \mathrm{C}$. However, at low substrate concentrations, an increase in cellulase concentration of $30 \mathrm{FPU} / \mathrm{g}$ of cellulose showed higher yields. This could be due to the low quantity of substrate and the presence of excess enzyme. Also, the high ethanol yields indicate the absence, or the presence at non-inhibitory concentrations, of inhibitors of the fermentation process.

Tables 4 and 5 also show the ANOVA analyzes for ethanol and $\mathrm{CO}_{2}$ concentration. For ethanol concentration all the variables except $X_{3}^{2}$ have a significant effect on ethanol concentration at the

Table 3

Analysis of variance (ANOVA) for ethanol yield ( $\left.Y_{\mathrm{EtOH}}\right)$ model as a function of temperature $\left(X_{1}\right)$, substrate $\left(X_{2}\right)$, enzyme $\left(X_{3}\right)$.

\begin{tabular}{lcrrrr}
\hline Source & Sum of squares & d.f & Mean square & F-value & \multicolumn{1}{c}{$p$-value } \\
\hline Model & 3676.62 & 9 & 408.51 & 10.81 & $0.0013^{*}$ \\
$X_{1}$ & 76.60 & 1 & 76.60 & 1653.49 & $<0.0001^{* *}$ \\
$X_{2}$ & 0.56 & 1 & 0.56 & 12.18 & $0.0397^{*}$ \\
$X_{3}$ & 2321.05 & 1 & 2321.05 & 50103.78 & $<0.0001^{* *}$ \\
$X_{1} X_{2}$ & 244.07 & 1 & 244.07 & 5268.65 & $<0.0001^{* *}$ \\
$X_{1} X_{3}$ & 33.58 & 1 & 33.58 & 724.95 & $0.0001^{* * *}$ \\
$X_{2} X_{3}$ & 0.90 & 1 & 0.90 & 19.35 & $0.0217^{*}$ \\
$X_{1}^{2}$ & 212.33 & 1 & 212.33 & 4583.54 & $<0.0001^{* * *}$ \\
$X_{2}^{2}$ & 133.80 & 1 & 133.80 & 2888.37 & $<0.0001^{* *}$ \\
$X_{3}^{2}$ & 6.24 & 1 & 6.24 & 134.66 & $0.00137^{*}$ \\
Residual & 302.39 & 8 & 37.80 & & \\
Total & 3979.02 & 17 & & & \\
$R^{2}$ & 0.924 & & & & \\
$R^{2} a d j$ & 0.838 & & & &
\end{tabular}

d.f., Degree of freedom.

* Significant.

** Highly significant.
Table 4

Analysis of variance (ANOVA) for ethanol concentration $\left(C_{\mathrm{EtOH}}\right)$ model as a function of temperature $\left(X_{1}\right)$, substrate $\left(X_{2}\right)$, enzyme $\left(X_{3}\right)$.

\begin{tabular}{lcrcrr}
\hline Source & Sum of squares & d.f & Mean square & \multicolumn{1}{c}{$F$-value } & \multicolumn{1}{c}{$p$-value } \\
\hline Model & 104.33 & 9 & 11.59 & 10.74 & $0.0014^{*}$ \\
$X_{1}$ & 2.75 & 1 & 2.75 & 73.30 & $0.0033^{*}$ \\
$X_{2}$ & 32.81 & 1 & 32.81 & 875.11 & $<0.0001^{* *}$ \\
$X_{3}$ & 49.90 & 1 & 49.90 & 1331.01 & $<0.0001^{* *}$ \\
$X_{1} X_{2}$ & 6.83 & 1 & 6.83 & 182.28 & $0.0008^{*}$ \\
$X_{1} X_{3}$ & 0.66 & 1 & 0.66 & 17.49 & $0.0249^{*}$ \\
$X_{2} X_{3}$ & 2.16 & 1 & 2.16 & 57.49 & $0.0047^{*}$ \\
$X_{1}^{2}$ & 2.11 & 1 & 2.11 & 56.26 & $0.0049^{*}$ \\
$X_{2}^{2}$ & 1.93 & 1 & 1.93 & 51.50 & $0.0055^{*}$ \\
$X_{3}^{2}$ & 0.05 & 1 & 0.05 & 1.29 & 0.3378 \\
Residual & 8.63 & 8 & 1.08 & & \\
Total & 112.95 & 17 & & & \\
$R^{2}$ & 0.923 & & & & \\
$R^{2}$ adj & 0.84 & & & &
\end{tabular}

d.f., Degree of freedom.

* Significant.

*** Highly significant.

Table 5

Analysis of variance (ANOVA) for $\mathrm{CO}_{2}$ concentration $\left(\mathrm{C}_{\mathrm{CO} 2}\right)$ model as a function of temperature $\left(X_{1}\right)$, substrate $\left(X_{2}\right)$, enzyme $\left(X_{3}\right)$.

\begin{tabular}{lcrcrl}
\hline Source & Sum of squares & d.f & Mean square & $F$-value & $p$-value \\
\hline Model & 103.85 & 9 & 11.54 & 7.37 & $0.0049^{*}$ \\
$X_{1}$ & 2.26 & 1 & 2.26 & 13.90 & $0.0336^{*}$ \\
$X_{2}$ & 30.30 & 1 & 30.30 & 186.47 & $0.0008^{*}$ \\
$X_{3}$ & 47.27 & 1 & 47.27 & 290.92 & $0.0004^{*}$ \\
$X_{1} X_{2}$ & 9.56 & 1 & 9.56 & 58.83 & $0.0046^{*}$ \\
$X_{1} X_{3}$ & 0.75 & 1 & 0.75 & 4.60 & 0.1213 \\
$X_{2} X_{3}$ & 3.02 & 1 & 3.02 & 18.61 & $0.0229^{*}$ \\
$X_{1}^{2}$ & 2.22 & 1 & 2.22 & 13.64 & $0.0344^{*}$ \\
$X_{2}^{2}$ & 1.91 & 1 & 1.91 & 11.75 & $0.0416^{*}$ \\
$X_{3}^{2}$ & 0.00 & 1 & 0.00 & 0.01 & 0.9112 \\
Residual & 12.53 & 8 & 1.57 & & \\
Total & 116.92 & 17 & & & \\
$R^{2}$ & 0.892 & & & & \\
$R^{2}$ adj & 0.771 & & & & \\
\hline
\end{tabular}

d.f., Degree of freedom.

${ }^{* *}$ Highly significant.

Significant.

95\% confidence level and ANOVA shows that enzyme loading $\left(X_{3}\right)$ is the most effective variable, followed by substrate concentration $\left(X_{2}\right)$ and interaction between temperature and substrate $\left(X_{1} X_{2}\right)$, suggesting a positive effect of enzyme loading on ethanol concentration (Fig. 4B). This is likely to occur due to the dependence of the SSF rate on the hydrolysis rate as enzyme loading is considered one of the most important factors in ethanol production from LCM. This becomes more evident as the effects between the variables $\left(X_{1} X_{2}\right.$, $X_{1}^{2}, X_{2}^{2}, X_{1}^{3}$ ) on ethanol concentration were less significant. Linde et al. [45] reported an ethanol concentration of $11.7 \mathrm{~g} / \mathrm{L}$ using the same raw material and Luo et al. [46], when evaluating the influence of enzyme concentration, reported an optimal ethanol concentration of $22.7 \mathrm{~g} / \mathrm{L}$ using the same enzyme loading at $35^{\circ} \mathrm{C}$. Faga et al. [14] studied the effect of reduced enzyme loading on SSF process and reported a reduction of glucan hydrolysis and lowered ethanol production. The synergetic enzymatic hydrolysis by cellulase supplemented with $\beta$-glucosidase greatly reduced the inhibition caused by cellobiose accumulation, thereby effectively improving SSF performance. In terms of $\mathrm{CO}_{2}$ concentration, ANOVA (Table 5) showed that the linear $X_{1}, X_{2}, X_{3}$, square $X_{1}^{2}, X_{2}^{2}$ and interaction $\mathrm{X}_{1} X_{2}, X_{2} X_{3}$ terms have a significant effect on $\mathrm{CO}_{2}$ concentration responses except $X_{3}^{2}$ and $X_{1} X_{3}$. The Pareto chart presented in Fig. $4 \mathrm{C}$ shows that the parameters that most strongly affect $\mathrm{CO}_{2}$ 

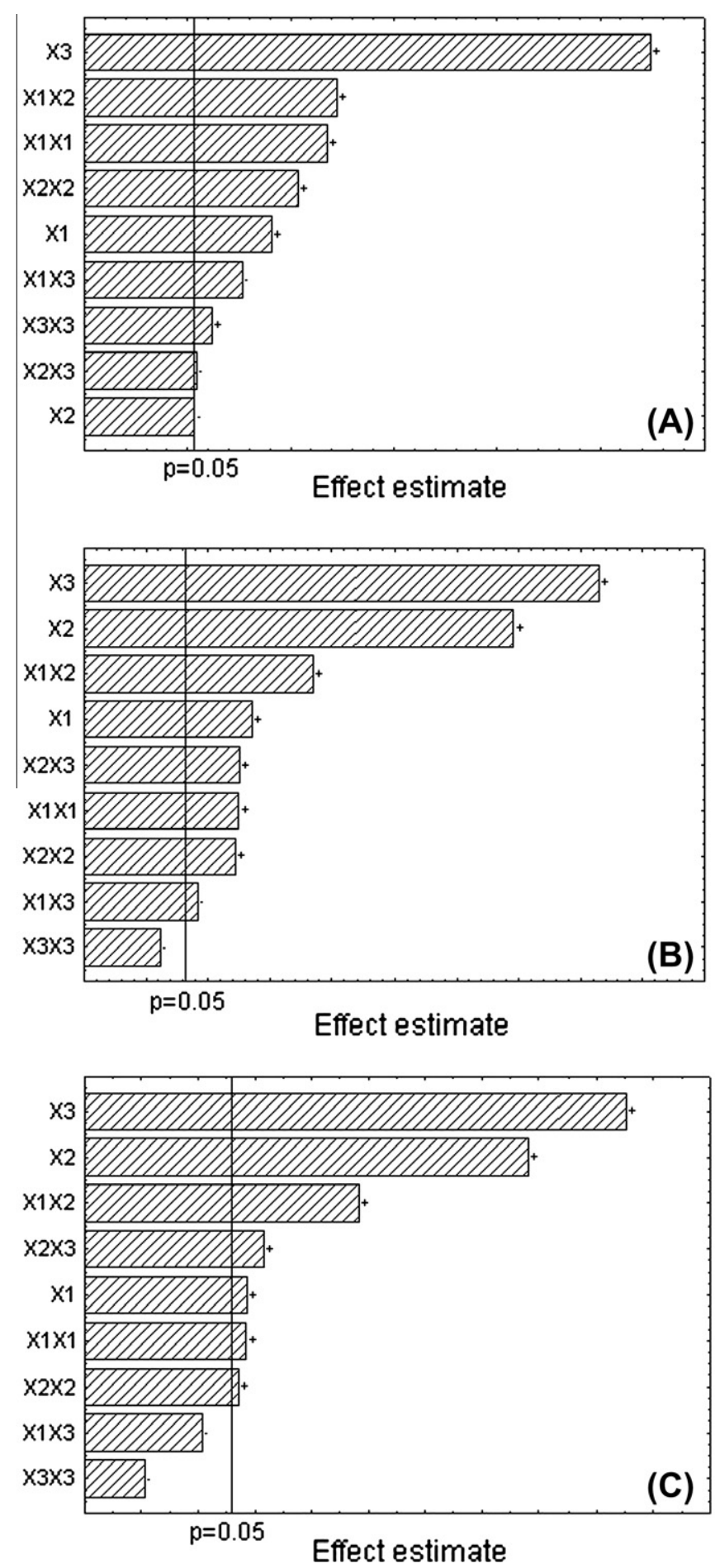

Fig. 4. Pareto charts for standardized effects of ethanol yield (A), ethanol (B) and $\mathrm{CO}_{2}(\mathrm{C})$.

production are enzyme loading, substrate concentration and the interaction between temperature and substrate concentration at the $95 \%$ confidence level. The positive effect of $X_{3}, X_{2}$ and $X_{1} X_{2}$, when raised from the lowest to the highest level is positive. By comparing Fig. 4B and $\mathrm{C}$, it can be observed that operating variables had similar effects on ethanol and $\mathrm{CO}_{2}$ concentration. This should be expected having in mind the stoichiometry of the conversion of glucose into ethanol and $\mathrm{CO}_{2}$ in the alcoholic fermentation process.
Response surfaces were drawn as three-dimensional plots of the second-order polynomial models (Eqs. (5)-(7)) as a function of the two most strongly influencing variables. Ethanol yield was plotted as a function of enzyme loading and temperature, for substrate values kept constant both at the highest $(+1)$ and at the lowest level $(-1)$ (Fig. 5A). Fig. 5A shows that a high ethanol yield could be obtained at a high enzyme loading and high temperature, both at low and high level of substrate concentration. This could be due to the depletion of the substrate and the presence of excess en-
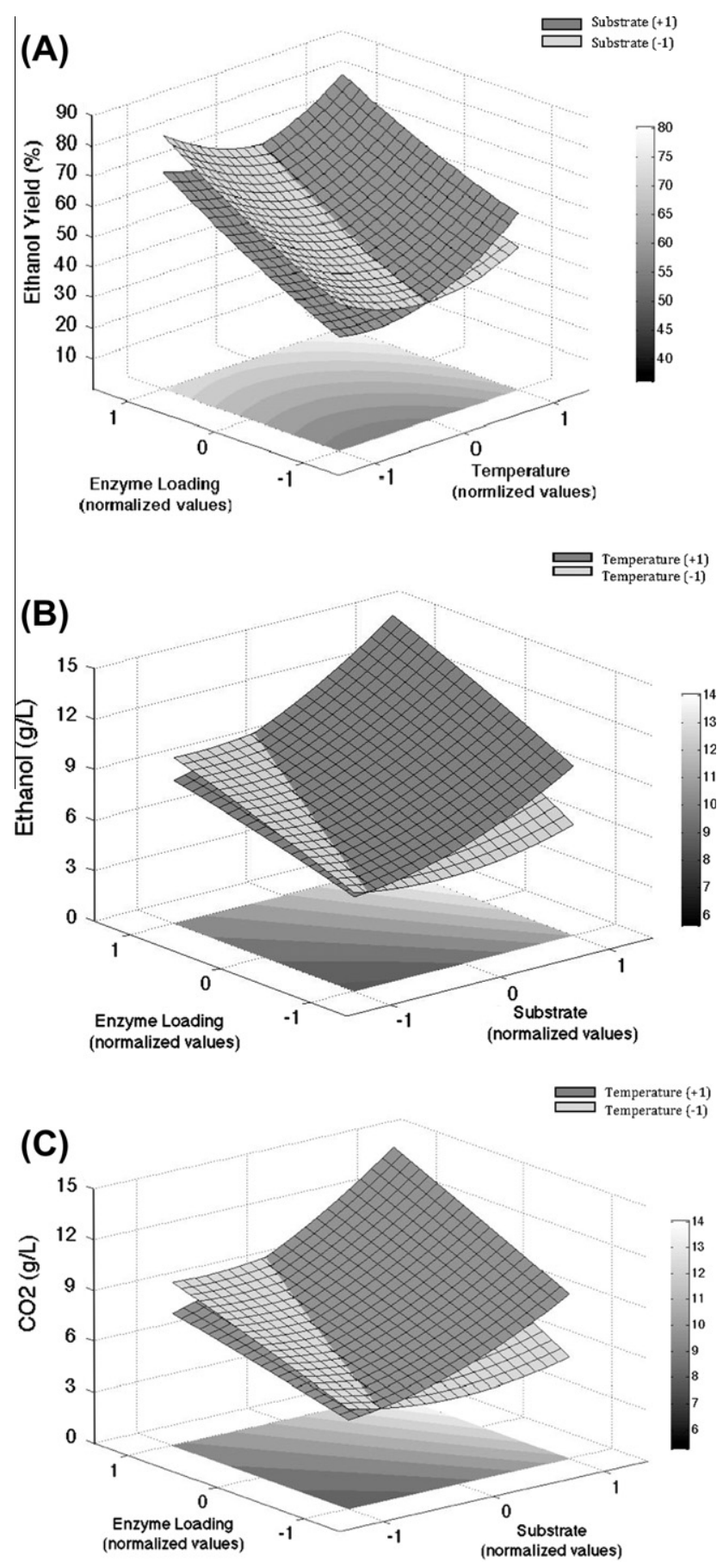

Fig. 5. Response surface and contour plot for SSF process. (A) Ethanol yield variation as a function of enzyme loading and temperature at two substrate levels; (B) Ethanol concentration variation as a function of enzyme loading and substrate at two temperature levels; (C) $\mathrm{CO}_{2}$ concentration variation as a function of enzyme loading and substrate at two temperature levels. 
zyme. At low enzyme loadings, increases in substrate concentration showed improvement in terms of conversion. However, at high enzyme loadings, increases in substrate concentration resulted in improved yield. In the case of ethanol and $\mathrm{CO}_{2}$ production, the most important variables were enzyme loading and substrate concentration and response surfaces were plotted as a function of these variables, for temperatures kept constant both at the highest $(+1)$ and at the lowest level $(-1)$ (Fig. 5B and $C$ ). Fig. $5 \mathrm{~B}$ and $\mathrm{C}$ shows that in order to obtain high ethanol and $\mathrm{CO}_{2}$ concentrations high enzyme loadings and substrate concentrations could be used at high temperatures. An increase in substrate concentration resulted in better ethanol production, which is due to the consumption of sugars by $S$. cerevisiae CA11. Temperature is a crucial factor for SSF process, so a compromise between the optimal temperatures for the actions of cellulolytic enzymes and yeast is needed. However, it must be pointed out that these results were obtained with a thermolerant yeast strain that made possible to perform the SSF at a temperature close to the optimal for the enzyme action, which was a real advantage.

\section{Conclusions}

Hydrothermal processing is an effective pretreatment that increased the cellulose concentration of wheat straw raw material, making it a good substrate for SSF. The results of this work show that the flocculating, thermotolerant $S$. cerevisiae CA11 strain has potential to be used for ethanol production in SSF process at $45^{\circ} \mathrm{C}$ and contributes to avoid one of the main disadvantages of SSF, while providing SSF yields comparable to those obtained with other fermenting yeasts. The experimental design used in the present study established efficient second-order polynomial models describing the effects of temperature, substrate concentration and enzyme loading on ethanol yield, ethanol and $\mathrm{CO}_{2}$ production by a SSF process using a thermotolerant flocculating yeast strain.

\section{Acknowledgements}

The authors H.A. Ruiz thanks to Mexican Science and Technology Council (CONACYT, Mexico) for PhD fellowship support (CONACYT grant number: 213592/308679) and L. Lima gratefully acknowledges the Fundação para a Ciência e a Tecnologia (FCT, Portugal) for PhD fellowship support (SFRH/BDE/15637/2006), also to Professor Juan Carlos Parajó, Patricia Gullón and Beatriz Gullón from University of Vigo, for the assistance in the materials preparation under hydrothermal processing and Francisco Pereira for yeast preparation analysis techniques.

\section{References}

[1] Renewable fuels association. Ethanol industry outlook; 2009. p. 5. <http:/ www.ethanolrfa.org/pages/annual-industry-outlook>; accessed [01.6.11]

[2] Linde M, Galbe M, Zacchi G. Simultaneous saccharification and fermentation of steam-pretreated barley straw at low enzyme loadings and low yeast concentration. Microb Tech Enzyme 2007;40:1100-7.

[3] Goh CS, Lee KT, Bhatia S. Hot compressed water pretreatment of oil palm fronds to enhance glucose recovery for production of second generation bioethanol. Bioresour Technol 2010;101:7362-7.

[4] Tan K, Lee K, Mohamed A. Role of energy policy in renewable energy accomplishment: the case of second-generation bioethanol. Energy Policy 2008;36:3360-5.

[5] FAOSTAT, Food and agriculture organization of the United Nations. <http:// faostat.fao.org/>; [accessed 05.07.11].

[6] Petersen PB. Separation and characterization of botanical components of straw. Agric Prog 1987;63:8-23.

[7] Romaní A, Garrote G, Alonso JL, Parajó JC. Bioethanol production from hydrothermally pretreated eucalyptus globulus wood. Bioresour Technol 2010;101:8706-12.

[8] Díaz MJ, Cara C, Ruiz E, Romero I, Moya M, Castro E. Hydrothermal pretreatment of rapeseed straw. Bioresour Technol 2010;101:2428-35.
[9] Ruiz HA, Ruzene DS, Silva DP, Quintas MAC, Vicente AA, Teixeira JA. Evaluation of a hydrothermal process for pretreatment of wheat straw-effect of particle size and process conditions. J Chem Technol Biotech 2011;86:88-94.

[10] Takagi M, Abe S, Suzuki S, Emerth G, Yata NA. A method for production of ethanol directly from cellulose using cellulase and yeast. In: Ghose TK, editor. Proceedings of bioconversion symposium, Delhi, 1977. p. 551-71.

[11] Olofsson K, Bertilsson M, Lidén G. A short review on SSF - an interesting process option for ethanol production from lignocellulosic feedstocks. Biotechnol Biofuels 2008;1:7.

[12] Alfani F, Gallifuoco A, Saporosi A, Spera A, Cantarella M. Comparison of SHF and SSF processes for the bioconversion of steam-exploded wheat straw. J Ind Microbiol 2000;25:184-92.

[13] Ballesteros M, Oliva J, Negro M, Manzanares P, Ballesteros I. Ethanol from lignocellulosic materials by a simultaneous saccharification and fermentation process (SFS) with Kluyveromyces marxianus CECT 10875. Process Biochem 2004;39:1843-8.

[14] Faga BA, Wilkins MR, Banat IM. Ethanol production through simultaneous saccharification and fermentation of switchgrass using Saccharomyces cerevisiae D5A and thermotolerant Kluyveromyces marxianus IMB strains. Bioresour Technol 2010;101:2273-9.

[15] Krishna SH, Reddy TJ, Chowdary GV. Simultaneous saccharification and fermentation of lignocellulosic wastes to ethanol using a thermotolerant yeast. Bioresour Technol 2001;77:193-6.

[16] Kadar Z, Szengyel Z, Reczey K. Simultaneous saccharification and fermentation (SSF) of industrial wastes for the production of ethanol. Ind Crop Prod 2004;20:103-10.

[17] Vianna CR, Silva CLC, Neves MJ, Rosa CA. Saccharomyces cerevisiae strains from traditional fermentations of Brazilian cachaça: trehalose metabolism, heat and ethanol resistance. Antonie van Leeuwenhoek 2008;93:205-17.

[18] Abdel-Banat BMA, Hoshida H, Ano A, Nonklang S, Akada R. High-temperature fermentation: how can processes for ethanol production at high temperatures become superior to the traditional process using mesophilic yeast? Appl Microbiol Biotech 2010;85:861-7.

[19] Nonklang S, Abdel-Banat BMA, Cha-aim K, Moonjai N, Hoshida H, Limtong S, et al. High-temperature ethanol fermentation and transformation with linear DNA in the thermotolerant yeast Kluyveromyces marxianus DMKU3-1042. Appl Environ Microbiol 2008;74:7514-21.

[20] Shi DJ, Wang CL, Wang KM. Genome shuffling to improve thermotolerance, ethanol tolerance and ethanol productivity of Saccharomyces cerevisiae. J Ind Microbiol Biotech 2009;36:139-47.

[21] Verstrepen KJ, Derdelinckx G, Verachtert H, Delvaux FR. Yeast flocculation: what brewers should know. Appl Microbiol Biotech 2003;61:197-205.

[22] Soares EV. Flocculation in Saccharomyces cerevisiae: a review. J Appl Microbiol 2011:110:1-18.

[23] Zhao XQ Bai FW. Yeast flocculation: new story in fuel ethanol production. Biotechnol Adv 2009;27:849-56.

[24] Vicente AA, Dluhý M, Ferreira EC, Teixeira JA. Modelling diffusion-reaction phenomena in yeast flocs of Saccharomyces cerevisiae. Bioprocess Eng 1998; 18:335-42.

[25] Domingues L, Lima N, Teixeira JA. Contamination of a high-cell-density continuous bioreactor. Biotechnol Bioeng 2000;68:584-7.

[26] Bjerre AB, Olesen AB, Fernqvist T, Plöger A, Schmidt AS. Pretreatment of wheat straw using combined wet oxidation and alkaline hydrolysis resulting in convertible cellulose and hemicellulose. Biotechnol Bioeng 2000;49:568-77.

[27] Ruzene DS, Silva DP, Vicente AA, Gonçalves AR, Teixeira JA. An alternative application to the portuguese agro-industrial residue: wheat straw. Appl Biochem Biotechnol 2008;147:453-64.

[28] Ruiz HA, Ruzene DS, Silva DP, Macieira Da Silva FF, Vicente AA, Teixeira JA Development and characterization of an environmentally friendly process sequence (autohydrolysis and organosolv) for wheat straw delignification. Appl Biochem Biotechnol 2011;164:629-41.

[29] Pereira FB, Guimarães PMR, Teixeira JA, Domingues L. Optimization of low-cost medium for very high gravity ethanol fermentations by Saccharomyces cerevisiae using statistical experimental designs. Bioresour Technol 2010;101:7856-63.

[30] Adney B, Baker J. Measurement of cellulase activities. NREL analytical procedure. National Renewable Energy Laboratory: Golden, CO; 1996.

[31] Gonçalves C, Rodriguez-Jasso RM, Gomes N, Teixeira JA, Belo I. Adaption of dinitrosalicylic acid method to microtiter plates. Anal Methods 2010;2:2046-8.

[32] Ruiz HA, Vicente AA, Teixeira JA. Kinetic modeling of enzymatic saccharification using wheat straw pretreated under autohydrolysis and organosolv process. Ind Crops Prod 2012;36:100-7.

[33] Dowe N, McMillan J. SSF experimental protocols-lignocellulosic biomass hydrolysis and fermentation. NERL analytical procedure. National Renewable Energy Laboratory: Golden, CO; 2001.

[34] Spindler DD, Wyman CE, Grohmann K, Mohagheghi A. Simultaneous saccharification and fermentation of pretreated wheat straw to ethanol with selected yeast strains and $\beta$-glucosidase supplementation. Appl Biochem Biotechnol 1989;20(/21):529-40.

[35] Varga E, Klinke HB, Réczey K, Thomsen AB. High solid simultaneous saccharification and fermentation of wet oxidized corn stover to ethanol. Biotechnol Bioeng 2004;88:567-74.

[36] Bely M, Sablayrolles JM, Barre P. Description of alcoholic fermentation kinetics: its variability and significance. Am J Enol Viticult 1990;41:319-24.

[37] Montgomery DC. Design and analysis of experiments. New York: John Wiley; 1997. p. 427-97. 
[38] Mok WSL, Antal MJ. Uncatalyzed solvolysis of whole biomass hemicellulose by hot compressed liquid water. Ind Eng Chem Res 1992;31:1157-61.

[39] Gullón B, Yáñez R, Alonso JL, Parajó JC. Production of oligosaccharides and sugars from rye straw: a kinetic approach. Bioresour Technol 2010;101:6676-84.

[40] Suryawati L, Wilkins MR, Bellmer DD, Huhnke RL, Maness NO, Banat IM. Simultaneous saccharification and fermentation of kanlow switchgrass pretreated by hydrothermolysis using Kluyveromyces marxianus IMB4. Biotechnol Bioeng 2008;101:894-902.

[41] Kristensen JB, Thygesen LG, Felby C, Jørgensen H, Elder T. Cell-wall structural changes in wheat straw pretreated for bioethanol production. Biotechnol Biofuels 2008:1-5.

[42] Walsum GPV, Allen SG, Spencer MJ, Laser MS, Antal MJ, Lynd LR. Conversion of lignocellulosics pretreated with liquid hot water to ethanol. Appl Biochem Biotechnol 1996;57(58):157-70.
[43] Negro MJ, Manzanares P, Ballesteros I, Oliva JM, Cabañas A, Ballesteros M. Hydrothermal pretreatment conditions to enhance ethanol production from poplar biomass. Appl Biochem Biotechnol 2003;105(108):87-100.

[44] Li H, Kim NJ, Jiang M, Won J, Nam H. Simultaneous saccharification and fermentation of lignocellulosic residues pretreated with phosphoric acid acetone for bioethanol production. Bioresour Technol 2009;100:3245-51.

[45] Linde M, Jakobsson E, Galbe M, Zacchi G. Steam pretreatment of dilute $\mathrm{H}_{2} \mathrm{SO}_{4}$ impregnated wheat straw and SSF with low yeast and enzyme loadings for bioethanol production. Biomass Bioenergy 2008;32:326-32.

[46] Luo P, Liu Z, Yang C, Wang G. Study of simultaneous saccharification and fermentation for steam exploded wheat straw to ethanol. Front Chem Eng China 2008;2:447-51. 